\title{
GCC Media Roles during the 2011 Arab Spring: An Analytical and Critical Overview
}

\author{
Abdullah K. Al-Kindi \\ Associate Professor \\ Dean of College of Arts \& Social Sciences \\ Sultan Qaboos University \\ kindik@squ.edu.om
}




\title{
GCC Media Roles during the 2011 Arab Spring: An Analytical and Critical Overview
}

\author{
Abdullah K. Al-Kindi
}

\section{Abstract}

The central aim of this paper is to critically analyze the role of the media during public protests that occurred in the GCC countries during 2011. These protests were part of what came to be called the "Arab Spring", which started in late 2010. Particular focus will be on how the Arab Spring resulted in fundamental changes and how various institutions played roles in this. The study draws on Gulf region literature about the Arab Spring in order to offer a critical and informed overview on the topic under discussion. The paper's main question is: what are the main roles played by the GCC media (old/new) during the public protests of 2011? The paper argues that the role of the media in the 2011 protests, while important, was rather limited and affected by the unique contextual characteristics of the media environment in the GCC countries.

Keywords: Media Role, GCC, Public Protests, Arab Spring.

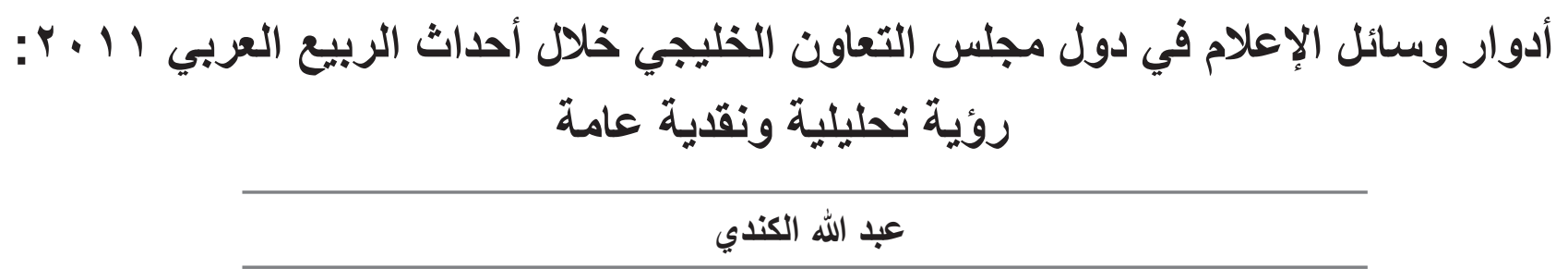

مستخلص

تسعى هذه الدراسة إلى تقديم روئة تحليلية ونقدية عامة لدور وسائل الإعلام في دول مجلس التعاون الخليجي خلال الاحتجاجات

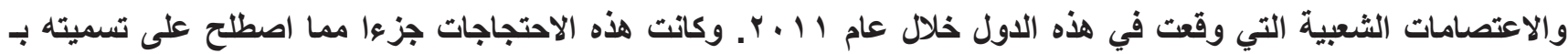

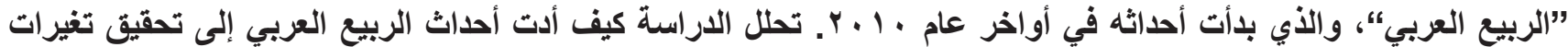
جذرية في عدد من المجالات، وما هي الأدوار التي لعبتها مختلف المؤسسات في تلك التغيرات. وسوف تركز الدراسة على الأدبيات

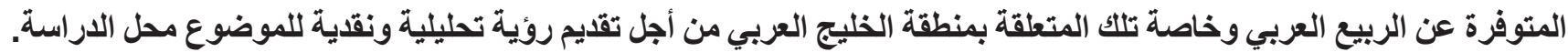
ويتمثل السؤال الرئيس لهذه الدراسة في: ما هي الأدوار التي لعبتها وسائل الإعلام (قديمها وجديدها) في دول مجلس التعاون

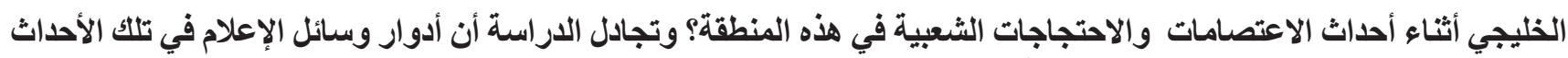
على الرغم من أهميتها، إلا أنها ظلت محدودة وتأثرت بخصائص بيئة العمل الإعلامي في هذه المنطقة.

كلمات مفتاحية: أدوار وسائل الإعلام، دول مجلس التعاون الظليجي، الاحتجاجات الثعبية، الربيع العربي. 


\section{Introduction}

At the end of 2010 and early in 2011 public protests swept through the Middle East and North Africa in a socio-political movement that became known as the "Arab Spring". Protesters were demanding wide-ranging reform, including an end to corruption and improved levels of social justice. The protests evolved into massive uprisings in some countries, while taking the milder form of quiet protests and sit-ins in others. In republics such as Tunisia, Egypt, Yemen, Libya and Syria, the masses demanded the complete elimination of the existing political systems. Less radically, in the Arab monarchies of Saudi Arabia, Jordan, Bahrain, Oman, UAE, Qatar, Kuwait and Morocco, protesters demanded only particular reforms and an end to corruption, though in some countries this turned into confrontation with the military and security forces, as in Bahrain, Saudi Arabia, Jordan and Oman (Ana Echague, 2013 and Zoltan Barany, 2012).

Different reasons were behind the Arab Spring 2010-2011, as well as the role of some key drivers which helped to shape the influence of this phenomenon.

The protests, starting in late 2010, appear to have arisen from an accumulation of problems and continued failures at the political, social and economic levels, which had been ongoing for decades in parts of the Arab world. Different theories and explanations have been offered, as one researcher writes:

"The Arab Spring does not constitute a single phenomenon or a disparate series of unrelated events. Rather, what we are witnessing across North Africa and the Middle East is the simultaneous unfolding of three grand, historic political processes: democratization; authoritarian adaptation/succession; and state failure" (Amichai Magen, 2012: 10).

He offers several underlying reasons. First is the collapse of confidence and trust in the elected presidential systems of countries like Egypt, Tunisia, Syria and Yemen. In effect, ruling groups in these countries turned them into "monarchies" and "hereditary" systems, but with façade elections and voting to provide a veneer of "democratic" décor.

A second reason involves demographic changes, mainly around issues of population, poverty and unemployment. The following statistics explain this effectively:

a. From 1970 to 2010, the population of the Arab region nearly tripled, rising from 128 million to 359 million inhabitants (Matin Beck, and Simon Huser, 2012: 6).

b. A UNDP report published in 2009 stated that about $20.3 \%$ of the Arab population was living below the two-dollars-a-day international poverty line in 2005 . The same report added that about 34.6 million Arabs were living in extreme poverty (UNDP, Regional Bureau for Arab States, 2009: 131).

c. In 2005 the overall average unemployment rate for the Arab countries was about $14.4 \%$ of the labor force, compared to $6.3 \%$ for the world at large, (Ibid: 28). More important, in the present author's opinion, is the following statement from the UNDP report, which explains some future consequences in this regard: "These trends in unemployment, coupled with population growth rates, indicate that Arab countries will need about 51 million new jobs by 2020. Most of those jobs will be essential to absorb young entrants to the labor force who will otherwise face an empty future" (Ibid: 28).

A third reason is rampant economic corruption found in many Arab countries. Some reported cases relate to the political elites or ruling families and groups. The most glaring examples reported came from Tunisia and Egypt, indicating that particular families and their members became deeply involved in economic corruption. Two researchers focusing on this, observe:

Corruption and lack of accountability, which sometimes turned the state and national resources 
into private property for people in power, reached levels that could not be ignored or unfelt by the citizen (Ziad Abdel Samad and Kinda Mohamadieh, 2011:12).

In addition to the above reasons for protest, there were other key influences at work. These include the number and activities of such civil society institutions as Non-Governmental Organizations (NGOs). According to the Information Center of the Arab Network, a total of 98,850 NGOs were operating across Arab countries by 2008. They were most numerous in such countries as Morocco $(38,500)$, Egypt $(27,068)$, and Tunisia (9065), and least so in countries like Oman (101), Kuwait (66), and Qatar (17) (Amani Kandil, 2010: 46).

The most important issue concerning the development of civil society institutions across the Arab World is the increased involvement of international non-governmental organizations (NGOs) in local and national life. Their involvement and state fear of negative international reports were putting increasing pressure on Arab governments, while civil society institutions at large and the general public were gaining both confidence and courage when confronting their local governments (USAID, 2011).

Then, too, it is believed that deep and wide penetration by the mass media has caused radical worldwide change at political, social, cultural, and economic levels. In the media industry itself, major change has been seen in terms of deployment speed, influence, and new professional skills.

A third factor is the proliferation of new media and their applications. Jon W. Anderson (1999) pointed to the issue of technology and new media, and its options provided for the next generation in the Middle East. The researcher identified some evidences of the proliferation of new media and its effects that will be caused in the future in the Middle East. Examples of this evidences include widespread use of various media, particularly satellite channels, mobile phones, and Internet which turned out to be a public avenue. Furthermore, the media messages became more universal and reached greater mass audiences regardless of geographic boundaries. The researcher argued that the people of the Middle East will be more interested in liberality than in democracy.

The term "new media" applies here to those areas of communication which are innovative in method and technology and those which have constantly renewed their mechanisms, styles and forms (Abdullah Al-Kindi, 2013). For the new media the Internet remains the most modern, important, and effective tool. The following remarks and statistics from the International Telecommunication Union (ITU) summarize the spread of the new media worldwide and in the Arab World during late 2010 and before the Arab Spring began (ITU, 2010. The World in 2010, Facts and Figures):

a. The number of Internet users in the world at the end of 2010 was over two billion users, of whom 1.2 billion were in developed countries.

b. The number of Internet users doubled between 2005 and 2010.

c. A number of countries, including Estonia, Finland and Spain, have declared access to the Internet as a legal right for citizens.

d. In developing countries $72.4 \%$ of households have a TV, but only $22.5 \%$ have a computer.

e. In developing countries only $15.8 \%$ have Internet access (compared to $98 \%, 71 \%$ and $65.6 \%$ respectively in developed countries).

f. By the end of 2010, half a billion households worldwide (or 29.5\%) have access to the Internet.

g. The percentage of Internet users in the Arab world at the end of 2010 was only $25 \%$ of the total population in this region.

h. There has been a widespread growth of innovative forms and applications among the new media relying on technology - namely YouTube, Blogs, Facebook, and so on. A report by the Dubai School of Government indicated that the total number of Facebook users in the Arab 
world at the end of 2010 was 21,361,863, and the country average for Facebook use was $6.77 \%$ (Dubai School of Government, 2011).

\section{Conceptual Framework}

The analysis in this study takes as a conceptual framework the media - government relationship in the GCC States. The analysis aims to show how this relationship contributes to characterize the media environments in this region by some special characteristics. The media authoritarian theory will be used in this regard to understand media government relationship in the GCC States. This theory is one of the most traditional and classical media theories which helped, and is still helping, in understanding media practices and relationships (Hamada Basyouni, 1993: 161). Identifying the applications of this theory, Denis McQuail (1994: 127-128) states that:

The application of authoritative theory is generally designed to protect the established social order and its agents, setting clear and close limits to media freedom.

Some applications of this theory could be found and understood by reading and analyzing (1) media laws and legislations, (2) ways of direct and indirect subsidies, (3) types of involvement in the editorial decisions, (4) levels of personal or self-censorship, and some other applications.

One cannot think out of these applications of the authoritative theory when studying media - government relationship in the GCC States. Governments in the GCC States run their own media outlets, but without ignoring their control and effects over the private media sector through sets of rules, directions, and ways of involvements in content and editorial decisions (Abdullah AlKindi, 2004: 146-148). Like in other developing and Arab countries, mass media in the GCC States are obliged to play some fundamental roles. Examples of these roles include, but are not limited to, fighting illiteracy, developing society, informing the public about world's events, in addition to other functions. Recently, some other functions were added to the media in the GCC countries, such as fighting terrorism, promoting Arabic and Islamic values, and protecting the gains achieved through development. The GCC governments established the mass media to bolster their own policies and propaganda, especially with the absence of political parties in the region. Although we cannot ignore the fact that the private sector owns some media outlets in the region, the governments of the region are still the main players. Thus, the mass media in the GCC countries are either a tool in the hands of the governing elite or monopolized by the political factions which use them as a medium to propagate their ideology. In these countries the mass media suffer from direct censorship by the State, beside the self-censorship, which is practiced by the editor-in-chief and journalists as well.

However, any deep understanding of the working environments of the GCC mass media cannot be achieved unless we understand the broader context, namely that of Arab mass media. According to William Rugh (1989: 71), the Arab press is classified into three categories, depending on their relationships with governments. These categories are: mobilization, loyalist, and diverse press. Mass media outlets are normally described as loyalist media.

Mass media and press have been loyal to governments of the GCC States right from their early inception. Although there are some contemporary initiatives and practices to adopting diverse press principles, the main character of the press and media in the GCC region is loyal. Beside the loyalist media and press, the governments in this region fully control the entire media landscape through the set of practices and procedures mentioned above. Accordingly, any question about the role played by mass media during Arab Spring in this region should be answered in light of full understanding of the media - government relationship within the authoritative theory. 


\section{Research Issue}

This study critically analyzes the media's role in recent societal changes which began across the GCC countries during and after 2011 - changes which came to be known as the "Arab Spring".

\section{Importance}

Very limited research has been conducted on the Arab Spring and media involvement in it with particular reference to the GCC, as opposed to comment on the wider Middle East and North Africa. Accordingly, the current paper's significance arises from the fact that it:

1- Opens further discussion about the Arab Spring and its effects on the GCC.

2- Encourages researchers to conduct more analytical and empirical studies on issues related to Arab Spring in the GCC.

3- Provides some key points about GCC media roles (old/new) in the public protests of 2011.

\section{Objectives}

This research aims to:

1- Identify the type of public protests that took place in GCC countries during 2011 and compare them with what occurred in other countries of the Arab World.

2- Detect the main roles played by the GCC media (old/new) during the public protests of 2011.

\section{Questions}

1- What type of public protests took place in the GCC during 2011 compared to those occurring in the wider Arab World?

2- What were the main roles played by the GCC media (old/new) during the public protests of 2011?

\section{Methodology}

In order to answer the above questions, this study uses a qualitative meta-analysis method. According to Lisa M. Given (2008: 506), meta-analysis is generally defined as "the analysis of analyses". She points out that:
Meta-analyses can be separated into two categories: integrative and interpretive studies. ... Interpretive analysis can be carried out using quantitative and qualitative approaches, does not have a priori concepts to test, and leads to the development of new interpretations from the analysis of multiple field studies (Lisa M. Given, 2008: 506-507).

In this study, the researcher uses the qualitative meta-analysis for the primary and secondary research and publications published in foreign and Arab periodicals concerning the role of the media in the Arab Spring and Gulf States in the context of political and media systems. Some international reports about the political, economic, and social changes before and during the Arab Spring are also analyzed and discussed. In the findings and discussion section, some analyses and comparisons between findings of previous studies and the views of the present researcher views will be made.

\section{Literature}

In the process of reviewing many studies on the Arab Spring and the role of media in the Arab world as a whole, it was found that research on the GCC countries is rather limited, though growing. One of these studies is by Nadav Samin (2012) entitled "Saudi Arabia, Egypt, and the Social Media Moment". The study critically analyses and compares between Egypt and Saudi Arabia during the Arab Spring and the role of social media in both countries. In this study, Samin (2012) confirms that many of the ingredients of a social media-driven revolution were in place in Saudi Arabia during the lead-up to the Arab Spring, but the society and restrictions imposed on social media clearly limited their roles and impact.

Baderya Al-Jenaibi (2011) published an empirical study that aimed to provide a comprehensive and accurate account of social media use in the UAE. She offered detailed comment and statistics, and concluded that the social media in the UAE, and in the Gulf region as a whole, have now established 
a place as an integral and interdependent component of society. Added to this study, Taghreed Alqudsi-Ghabra et al. (2011) examined penetration by the Internet and its role in the GCC countries and described it as a "vehicle of change". They provided a deep analysis of how the GCC governments reacted to the new media before and during the Arab Spring, and how these reactions lacked unity. Their study results show that a lack of clear understanding of the new paradigms of power emerging in their societies led governments in this region to respond inconsistently. The results also suggest that conflict in this region will continue between authorities and new media activists. Accordingly, GCC people are promised a future of further change. In this context also, J. E. Peterson (2012) examined the role of social media in disseminating ideas and information, in circulating grievances, and in organizing demonstrations. These activities, according to Peterson, were ongoing even before the Arab spring, though regional governments reacted directly and actively only after protests began on the streets. Considering the social media as a means of informal participation in Gulf affairs, Peterson found a sharp increase in their use, though with authority control making this use risky, citing examples of GCC governments punishing new media activists with arrest and jail. By contrast with the paucity of studies on the Arab Spring and media in the GCC, there are more studies on this topic that address the Arab world in general. These mainly focus on the new media and particularly on the social media. One conducted by Madeline Storck (2011) analyzes how Egyptian activists used social media networks (chiefly Facebook, Twitter, YouTube and weblogs) as tools for generating, organizing, and creating awareness of political mobilization in the protests that took place in Egypt in early 2011. Storck concluded that the "inherent characteristics of social media and the Internet were able to foster the necessary requirements for collective action". What disappointed him, however, was that after the uprising the social media were less useful in translating protesters' needs and demands into political reality. Another study, by Simon Cottle (2011), revealed the different roles played by the media and communication in all events related to the Arab Spring. He refused, however, to label the Arab Spring as the 'Twitter or Facebook Revolution'. In the same vein, Minavere Vera Bardici (2012) confirmed the importance of new media outlets and technologies, but stated: "they alone don't make revolutions". She, like Simon, refused to accept the description of the Egyptian uprising by some commentators as the "Facebook Revolution". Instead, she believes that historical, cultural, social and political contexts should be examined as well as understanding how the media landscape is related to all previous contexts. Bushra Al-Rawi (2012) researched the role of social media in social change. According to her, real political change in the Arab World began first in the streets, before the media assumed a role. She argues that only afterwards did the social media give important support to the street activists, encouraging change through the provision of information and ideas. Her study suggests that reform and change activists should benefit from the Internet revolution in terms of their organization, management, communication, and political struggles.

Other studies on the new media have analyzed data inputs and outputs and how the public used this communication opportunity during the Arab Spring. For example, Sean Aday Sean and some other researchers (2012) wrote an article called "Blogs and Bullets II: New Media and Conflict after the Arab Spring" and produced some interesting results. They concluded that new media outlets were more likely to spread information outside a region than within it, and that these outlets did not appear to play a significant role in either in-country collective action or regional diffusion, while not denying the new media's importance in the Arab Spring. They also found it difficult to separate the new and old media. Aday (2013) then led another group study on media consumption during the Arab Spring. In contrast with many studies on the subject, which focus on how the new media have 
"enabled participants and spectators to produce and circulate protest-related content", this study took a different direction. It investigated consumption patterns of Arab Spring-related content using a data set constructed by combining archived Twitter material with metadata drawn from the URL service Bit.ly. Two main questions were raised: First, were links posted to Twitter followed primarily by individuals inside the affected country, within the Arab World region, or by those outside this area? And second, who attracted more attention online protesters and other non-elite citizens or traditional news organizations? Findings indicate that most attention to Arab Spring content came from outside the Arab World; and, further, that the traditional "old" mass media, rather than the citizens' media, overwhelmingly held the world's attention during the protests. The main conclusion was that Twitter as a social network was effective "as an information channel for non-Arab World onlookers but less so for protesters on the ground".

The literature also contains studies on changes in traditional media outlets, one being Rasha Owais's "Arab Media during the Arab Spring in Egypt and Tunisia: Time for Change" (2011). The emphasis here is on Egypt and Tunisia and the "changes" and "purifications" that have begun to occur in media outlets in these two countries. Owais cites examples of how Tunisian journalists and media demonstrations succeeded in changing editorial team practice on national television and in newspapers. In Egypt, journalists called for many changes, such as the election of a new board for their association and the need for new blood to be brought into the stagnant national media. Owais believes that all Arab media organizations need to benefit from the media protesters' experience in both Egypt and Tunisia and should call for similar changes. She suggests in her conclusion two important lessons for all Arab media organizations: break the tradition of blindly supporting whoever is in power and start creating truly independent media outlets. During the uprising itself Mark Peterson (2011) studied Egypt's media ecology, replicating a study published by William Beeman (1984) on the media ecology of Iran before, during, and after its revolution. Two new elements appear in the Egyptian experience which was missing in Iran's much earlier experience: satellite television and social media. Peterson defined media ecology as a "dynamic, complex system in which media technologies interact with each other and with other social and cultural systems within a particular social field, and the ways these interrelationships shape the production, circulation, transformation and consumption of images, texts and information within this system". Peterson then explored four main topics: Egyptian media ecology before the uprising; media functions during the uprising; the role of international media; and Egyptian media after Mubarak's regime. The important conclusion of this study was that "whatever the ultimate political outcome of the uprisings, the media scope of Egypt post revolution will be significantly different from what it was before January 25" (Peterson, 2011: 1). Zvi Bar'el (2012) analyzed trends and perspectives within Egypt's state-owned media after the uprising. He reported calls from intellectuals and journalists for stateowned newspapers to be transformed into private companies and to conduct complete purification of their old, corrupt management. Some wanted drastic legal amendments to guarantee press freedom and transformation of media outlets into the "press of the people". Bar'el concluded that the "old guard" of the Egyptian media had successfully adopted the new discourse produced by the revolution.

\section{Findings and Discussions}

This section of the study will be divided into two parts to provide answers to the above questions as follows:

\section{1- The GCC public protests 2011}

According to some international reports and studies (mainly those conducted and published by the United Nations), many analysts and researchers were surprised that the GCC countries 
in 2011 could face challenges and public protests and in some cases as strong as those in other Arab countries. The reasons for this surprise might be better understood after considering the following:

- The GCC countries are ruled by monarchal families, some of them having been in power since the $18^{\text {th }}$ century. Further, with the exception of Bahrain, there are no real or authorized political oppositions in these countries.

- International reports by the UNDP in 2009 categorized all six GCC countries as "High" on the Human Development Index (UNDP Regional Bureau for Arab States 2009:229).

- The GCC's annual population growth rate is generally considered as acceptable when compared to that of the wider Arab world. The only two exceptions are the UAE and Qatar, where the growth (1975-2005) was considered as relatively high ( $7 \%$ in UAE and $5 \%$ in Qatar) (Ibid: 232).

- The total number of unemployed in all GCC countries between 1996 and 2005, according to the UNDP, was 465,000. Most were concentrated in Saudi Arabia $(321,000)$ and Oman (51,000) (Ibid: 246).

Because of some or all of the above facts, GCC protests and sit-ins surprised many observers and commentators. But the Arab Spring, which surprised the whole world, also affected the GCC's people and led them to call for reform and change. Moreover, results achieved by the masses in countries such as Tunisia and Egypt after the fall of long-established political systems there inspired people in other parts of the Arab world, including the GCC, to adopt the same behaviour and slogans. Generally speaking, protests in the GCC were an opportunity for the masses to raise hitherto unspoken demands and press governments to discuss and satisfy public needs. Solvia Colombo (2012:4) describes this situation as follows:

In spite of the fact that political, economic, demographic and social conditions in GCC countries differ dramatically from North African and Middle Eastern realities, analogic thinking, a sense of commonality and the borrowing of mobilization frames, repertoires and modes of contention, made the outburst of unrest in the Gulf region possible, particularly in the least oil-rich GCC countries of Oman and Bahrain. In these countries the impact of such factors was compounded by the crucial importance of shared culture, history and identity across the whole Arab world.

Appendix (1) of this study summarizes the protests and sit-ins in the GCC countries. Several points helpful for an understanding might be drawn from the table:

- Bahrain and Oman witnessed the strongest level of protests in the GCC countries. From the political and socio-economic perspective, this could be linked to the level of living standards and individual incomes in Bahrain and Oman. The two countries are the least affluent countries and the least two oil producers in the GCC region (Armando Schmidt and Joachim Vannahme, 2012). But these should not be seen as the only reasons; a much deeper understanding is needed. Politically, Bahrain has a different model in the GCC region, being the region's only country that allows the existence of political opposition represented in the parliament and in social life in general. In Oman, the political system, under the leadership of Sultan Qaboos bin Said since 1970 , has been characterized by tolerance and openness to opponents from the 1970s up to the protests of 2011.

- The United Arab Emirates and Qatar did not witness real public protest, and calls for reform were limited. In the UAE, the main demand was for strengthening the role of the Federal National Council (parliament) and for the election of all members. In Qatar, there were calls for the Amir to reduce or cease support for Western foreign policy worldwide and particularly in the Middle East. This might be 
related to living standards in both countries when compared to some international levels (UNDP Regional Bureau for Arab States, 2009: 131).

- High living standards did not completely eliminate calls for reforms in different areas of life. Perhaps it was not the right moment in both countries and the protests did not find the environment suitable for taking advantage of the Arab Spring winds.

- The masses in Kuwait did not invest in their political openness, which is unique in the Gulf region. Public protests were weak and went no further than complaints about the dismissal of the prime minister and a section of the population without citizens' rights ("bidun"). Political dialogue and disagreement in Kuwait are continuous and very interactive in the National Assembly (Al-Umah Council) and in the mass media and other forums (Zoltan Barany, 2012: 9).

- People in Saudi Arabia did not benefit from the events of the Arab Spring; or rather they couldn't because the security forces stopped some of the marches and protests, especially those planned in the capital Riyadh. The government also relied on the intervention of religious scholars, especially the Authority of Senior Scholars, who issued a "fatwa" prohibiting demonstrations (Ibid: 8).

- Protests began in the Gulf States after the start of the Arab Spring. In Oman they began with the "First Peaceful Green March" on the $17^{\text {th }}$ of January 2011 (Marc Valeri, 2015); they began in Bahrain on the $14^{\text {th }}$ of February 2011 (Bahrain Protests 2011/12. Special Coverage https://globalvoices .org/). This demonstrates how the Arab Spring encouraged the launch of public protests in the GCC states.

- Protests in countries like Oman and Bahrain extended to severalareas, including the capitals. The first and second Green Peaceful March in Oman, for example, took place in Muscat. Later protests took place in other towns and areas, but the capital was the main center. In Bahrain, the protests and sit-ins were also concentrated in the capital, Manama. Security forces, on the other hand, prevented demonstrations and protests in the Saudi capital, Riyadh. The same applied to Kuwait, where the capital did not see large protests. Most demonstrations and marches took place in areas like Al-Jahra and Sulibia, far from the capital.

- Government decisions taken by GCC states to deal with public protests were varied and included different types of responses. They included the following (Peterson, J. E., 2012, Armando Schmidt and Joachim Vannahme, 2012, Zoltan Barani 2012, Matt J. Duffy, 2013, Ana Echague, 2013 and Marc Valeri, 2015):

- A request for military intervention by the Peninsula Shield Forces to deal with public unrest and secure stability (Bahrain).

- Declaration of a state of emergency (Bahrain).

- Formation of a new government (Oman).

- Dismissal of ministers and officials and new appointments made (Bahrain, Oman, and Saudi Arabia).

- Legislative powers taken to control parliament (Oman).

- Creation of new civilian authorities (Bahrain, Oman, and Saudi Arabia).

- Election of municipal councils (Oman and Saudi Arabia).

- Provision of jobs (Oman, Bahrain, and Saudi Arabia).

- Financial support for unemployed citizens (Oman and Saudi Arabia).

- Loan packages for citizens (Saudi Arabia).

- The building of social housing (Saudi Arabia).

- Among GCC government responses to the protests (military-security, political, socioeconomic solutions), the researcher believes that the economic response was the clearest and most effective. 


\section{2- GCC media roles during the 2011 public protests}

The traditional mass media in the Arab Gulf states played a very limited role in the protests that occurred, not generally exceeding routine daily reportage. It was also clear that there were no supportive attitudes to these protests in the traditional media, whether governmentor privately-owned. This was expected and the reasons appear later in this part of the study. The same observation applies to the new media, described by some researchers as the primary engine of the Arab Spring and by others, repeatedly, as the "Facebook Revolution". The researcher takes issue with these views, arguing that, despite the degree of Internet use and prevalence of social networks in the GCC populations, these claims lack firm evidence. However, the following is a more accurate list of some of the roles played by the mass media, both "traditional" and "new", during the protests:

1. Providing routine and censored daily news coverage of the protests on radio, television, and in newspapers (in all media outlets in the GCC countries). One can describe radio and television coverage of these protests in a country like Oman, for example, as routine and more of one "way informative" type of coverage. In Bahrain, an Independent Commission of Inquiry investigated the public protests of 2011 and evaluated the media and journalists' situations before and during the protests. The Commission report, according to Duffy (2013:19) states that: These journalists alleged that the media in Bahrain is heavily censored by the (government) and does not represent the views or outlook of the vast majority of Bahrainis. It was alleged that in some cases, simply expressing a point of view or factual information that differs from or contradicts the (governments) position could result in the suspension or termination of employment at a media organization.

2. Limited and restricted calling for public protests in the social media and establishing online dialogue. Some few examples in this role come from countries like Bahrain, Kuwait, and Oman. Yet the public utilization of social media during 2011 protests in the region was very limited and minimal, and even restricted in some cases. In Saudi Arabia, for example, Nadav Samin (2012:7) describes how the regime in Saudi Arabia reacted toward a Facebook page which called for nationwide protests against the regime on March 11, 2011:

March 11 was a strange day in Saudi Arabia. Police cars patrolled the streets constantly, and all shops were shuttered. Helicopters flew overhead in certain areas, and there was a palpable sense of unease. That an anonymous Facebook call could trigger a nationwide security service mobilization demonstrates the enormous power of social media and the Internet.

3. Publishing bold interpretations and in-depth analysis of the protests in the new media. Some of these interpretations pointed a finger at the state and its institutions as the main causes of the protests. In Oman, for example, the electronic magazine Al-Falaq electronic magazine published a series of articles reporting and interpreting the protests, some of them very critical and a challenge to so-called "red lines"(http://www.alfalq.com/).

4. Proposing serious initiatives for dealing with the protests and related events and mentioning expected reforms. One initiative involved "Discussion Salons", organized by Oman's Alroya daily paper, which invited policy makers, intellectuals, writers, and interested commentators to exchange ideas and discuss possible changes. These deliberations were then published in detail for readers to consider (http://alroya.om/ar/).

5. Providing space in some newspapers for articles carrying views and ideas totally opposed to what the same papers were expressing before the protests. These types of articles, however, were to gradually diminish in frequency, until they 
eventually stopped completely. The present writer sees these articles as very good measures of the media freedom found during the protest period. However, their disappearance after the protests ended also proves that the media environment in the GCC countries was not yet ready for a significant extension of media freedom. The researcher noted the gradual disappearance of some type of 'strong' and 'opposed' articles in some Omani private dailies immediately after announcing the Cabinet change in March 2011. Furthermore, an article described the same situation that happened in Bahrain entitled "Controlling the Tale: Press Flourished for Short Time and then Dulled" (Translated from Arabic by the researcher). The article indicated how the independent journalists in Bahrain after five years of public protests became unable to criticize and write freely about what was happening in this island. Most of them, provided information and reports for international media and insisted that their names not mentioned. (http://www.watanserb. com/archive1/reports/).

6. Calling for national dialogue to study needed reforms and how to achieve them. The media in Oman and, particularly in Bahrain, raised this issue repeatedly.

It is, then, obvious from the above details just how limited and secondary the media roles were. Furthermore, GCC media participation in the Arab Spring was of a diluted nature and far weaker than the lively and passionate discussion in the open squares of towns and villages. Hence, it is inaccurate to describe public protest in the GCC countries, and even in the Arab World, as a social media revolution.

Mass media institutions themselves were among those targeted for reform in the Arab World generally, and particularly in the GCC region. Reforms called for included media leadership change, change in media policies and rules, more open spaces for freedom of expression, and other demands. Associated with these calls, fresh discussions and debates occurred both during and after the public protests. Debate on the concept of "state media" and how this might replace the concept of "government media" is a good example of the fresh thinking taking place. There was some promise, in terms of practice, that the GCC's media institutions were beginning a transition towards more openness by applying the concept and practices of "state media". In this way these institutions could gain more free space, allowing them, in the highest interests of the state, to evaluate and criticize government policies and projects.

However, the problem did not lie at the level of appropriate concepts and terminology, but rather with the actual practices and rules arising from them. In Oman, for example, the media sector, one of several sectors affected by public protest, underwent reforms at the levels of leadership and structure. Prior to the protests, a royal decree issued on 19 October 2010 established the Public Authority for Radio and Television, which was to be independent of the Ministry of Information (http://part.gov.om/part/). Following the events of 2011, specifically on 22 October 2011, a royal decree announced the appointment of a chairman for the Public Authority for Radio and Television - a technocrat and intellectual, well-known in the local cultural community, and holder of a doctorate in the field of translation studies. Another royal decree, issued on 29 February 2012, appointed as Minister of Information another technocrat and intellectual, well-known locally and internationally as a professional photographer, and a Ph.D. holder in media studies. Both leading figures strove at once to open a space for diverse media content which would to some extent reflect the principles and applications of "state media". Reflecting on that promising beginning, the German News Agency on 8 April 2012 published a report entitled "Media Leading Oman to Extraordinary Changing Period" (http://www.dpa.de/683.0.html).

But these media step changes, in Oman and elsewhere across the region, did not continue at the same level of decisiveness, and have yet to 
achieve the growth and weight required for forming and establishing new concepts and applications in the media environment. Thus, the lesson again is about applications which accumulate experience, not about abstract terms and concepts. The following examples explaining this were published in a detailed report by the Doha Centre for Media Freedom in 2013 on the media laws and regulations of the GCC countries: (Matt J. Duffy, 2013).

- May 2012, in Bahrain there were official calls for new regulations on social media because of the "irresponsible use of such media", instead of "relaxed censorship" by the government as recommended by the media reform plan after 2011.

- March 2012, the Ministry of Information in Kuwait prosecuted a newspaper editor over two articles he published, resulting in a sixmonth prison sentence and the suspension of the daily newspaper Al-Dar.

- April 2012, in Kuwait there were official calls for more regulation of social media sites such as Twitter following cases of alleged blasphemy and sectarianism.

- April 2011, in Saudi Arabia two bloggers were detained along with 160 other Saudis accused of instigating unrest.

- April 2011, the UAE government arrested five activists who were among 130 people who signed a petition calling for reforms in the country.

- The government-owned telecom firms in the UAE blocked access to the site carrying the above news by citing the government's online "prohibited content guidelines".

- March 2011, during the upheavals of the Arab Spring, Qatar authorities apprehended and arrested some bloggers.

- May 2012, the government in Oman arrested two journalists from the Muscat daily newspaper Al-Zaman.

Thus, the GCC masses may not have used the new media effectively during the protests in 2011 because of governments' control of networks and their ability to cut connections when they wanted. But this does not mean that new media networks will always be under government control. It should be realized that new media development is technically very fast and sharp. Accordingly, in practice it will be very difficult to control or proscribe these networks locally or within a national framework. It would not be an appropriate solution, therefore, to prevent the flow of information and ideas through these means by using direct censorship or cutting communication lines. Instead, national governments and societies should consider strengthening pluralism and diversity in media discourse, opening more space for freedom of expression. Not to deny the importance of empowering civil society institutions, encouraging accountability, spreading the values of transparency and the need to combat corruption.

\section{Further recommendations}

These might include the following:

1- Conduct empirical/analytical studies to measure the actual volume of media attention to the public protests of 2011.

2- Conduct field/survey studies to determine media uses and achievements during the protests of 2011.

3 - Study the changes in media policies and regulations in the GCC countries made after the public protests.

4- Review communication policies in the GCC countries.

5- Devise legal and legislative frameworks to facilitate and protect the applications of "State media".

6- Enhance the application of "citizens' media".

7-Benefit from widespread Internet use and social network penetration to provide increased information and interpretation of societal developments. 


\section{References}

Abdel Samad, Z. and \& Mohamadieh, K. (2011) 'The Revolutions of the Arab Region: Socioeconomic Questions at the Heart of Successful Ways Forward', p. 12, (in) Perspectives: Political analysis and commentary from the Middle East. 2 May 2011. Special issue entitled "People's Power: The Arab World in Revolt". Heinrich Böll Stiftung: Germany. Pp. 112-118. https://lb.boell.org/ sites/default/files/perspectives_-_issue_2.pdf. accessed 20th August 2015.

Aday, S. et al., (2013), 'Watching From Afar: Media Consumption Patterns around the Arab Spring', (in) American Behavioral Scientist, XX (X). Sage Publications: UK. Pp. 1-21. http:// henryfarrell.net/wp/wp-content/uploads/pdf. accessed 20th August 2015.

Aday, S. et al., (2012) 'Blogs and Bullets II: New Media and Conflict after the Arab Spring'. United States Institute of Peace: Washington, DC. Peaceworks No. 80. http://www.usip.org/sites/ default/files/pdf. accessed 20th August 2015.

Alfalaq is an Omani electronic magazine. All the magazine's articles are available in its electronic archive: www.http://www.alfalq.com/. accessed 20th August 2015.

Al Jenaibi, B. (2011) 'Use of Social Media in the United Arab Emirates: An Initial Study', (in) Global Media Journal, 1, issue 2. (Arabian Edition) Summer/Fall. Vol. 1, No. 2. American University of Sharjah: UAE. Pp. 3-27. http://www.gmjme..com/ gmj_custom_files/volume1_issue2/. accessed 20th August 2015.

Al-Kindi, A. (2013) 'Effects of New Media on the 'Cultural Values sin The Arab World', (in) Les Annales De L'Universite' D' Alger, . Issue no. 23, June 2013: University of Algeria: Algeria. Pp. 254-300.

Al-Kindi, A. (2004) 'FREEDOM of Mass Communication in Oman: Analysis of Publication
Laws and Media Instructions', (in) Journal of Human Sciences. Issue no. 9, winter 2004. University of Bahrain: Manama. Pp. 135-177. Alqudsi-ghabra, T. M. and others (2011) 'The Internet in the Arab Gulf Cooperation Council (AGCC): Vehicle of Change', (in) International Journal of Internet Science, 6, issue 1. Vol. 6, issue no.1. University of Deusto: Spain. Pp. 44-67.

Al-Rawi, B. (2012) 'The Role of Social Media in Social Changes: A Theoretical Approach', (in) Al Bahith Al-aalami, Baghdad, issue no. 18. Baghdad University: Baghdad. Pp.94-112. http://www. ijis.net/ijis6_1/ijis6_1_alqudsi-ghabra_et_al.pdf. accessed 12 July 2015.

Alroya is an Arabic daily newspaper .www.http:// alroya.om/ar/. accessed 20 August 2015.

Anderson, J. (1999) 'Technology, Media, and the Next Generation in the Middle East'. Paper delivered at the Middle East Institute, Columbia University, Sept. 28, 1999: New York. The paper available at: http://www.mafhoum.com/ press3/104T45.htm. accessed 20th August 2015.

Bahrain Protests 2011/12. https://globalvoices. org/specialcoverage/2012-special-coverage/ bahrain-protests-2011/. accessed 20th August 2015.

Barany, Z. (2012) 'The Arab Spring" in the Kingdoms'. Arab Center for Research and Policy Studies: Doha. http://english.dohainstitute.org/ file/get/.pdf. accessed 20th August 2015.

Bar'el, Z. (2012) 'Reshaping the Hegemony: State-Owned Media in Egypt after the Revolution', (in) Global Media Journal (German Edition). Vol. 2, No.1, Spring/Summer 2012. Global Communication Association (www. globalcomassociation.com). Pp. 1-17. http:// www.db-thueringen.de/servlets/DerivateServlet/ pdf. accessed 20th August 2015. 
Bardici, M. (2012) A Discourse Analysis of the Media Representation of Social Media for Social Change - The Case of Egyptian Revolution and Political Change. M.A. Thesis. Malmö University: Sweden. https://dspace.mah.se/bitstream/ handle/pdf. accessed 20th August 2015.

Basyouni, H. (1993) The Role of Mass Media in Decision Making in the Arab World, Arab Unity Studies Center: Beirut.

Beck, M. and Hüser, S. (2012) 'Political Change in the Middle East: An Attempt to Analyze the "Arab Spring". GIGA (German Institute of Global and Area Studies) Research Unit: Institute of Middle East Studies. Hamburg: Germany. P.6. http:// papers.ssrn.com/sol3/papers. accessed 20th August 2015.

Colombo, S. (2012) 'The GCC Countries and the Arab Spring. Between Outreach, Patronage and Repression'. IAI Working Papers. Instituto Affari Internazionali: Roma. P.4. http://www.iai.it/sites/ default/files/pdf. accessed 12 July 2015.

Cottle, S. (2011) "Media and the Arab uprisings of 2011: Research notes", (in) Journalism. Sage: UK. Pp. 647-659. The online version of this article can be found at: http://jou.sagepub.com/content/. accessed 5 September 2015.

Dubai School of Government (2011) Arab Social Media Report. Vol.1, No. 1. Dubai: United Arab Emirates. Available at: http://www.dsg.ae/en/ asmr3/index.aspx?AspxAutoDetectCookieSupport. accessed 5 September 2015.

Dpa. 8.4.2012 'Media Leading Oman to Extraordinary Changing Period', at: www.http://www.dpa. de/683.0.html. accessed 5 September 2015.

Duffy, M. J. (2013) Media laws and regulations of the GCC countries: Summary, analysis and recommendations. Doha Centre for Media Freedom: Doha. Available at: http://www.dc4mf.org/sites/ default/files/gcc.pdf. accessed 5 September 2015.
Echagüe, A. (2013) (Ed.) The Gulf States and the Arab Uprisings. FRIDE and the Gulf Research Centre. Artes Gráficas Villena: Spain. http://fride. org/ pdf. accessed 5 September 2015.

Given, L. M. (2008) The SAGE Encyclopedia of Qualitative Research Methods. Vol. 1\& 2. Sage Publications, Inc.: London. http://www.stiba. malang.com/up;oadbank/pustaka/pdf. accessed 12 July 2015.

ITU (2010) The World in 2010: Facts and Figures. Available at: http://www.itu.int/ITU-D/ict/ material/FactsFigures2010. accessed 5 September 2015.

Kandil, A. (2010) 'A critical review of the literature About the Arab Civil Society', (in) proceeding of Regional Conference Entitled "Research on Civil Society Organizations: Status and Prospects". Dead Sea - Jordan 26-28 January, 2010. Pp. 1-51. http://foundationforfuture.org/en/pdf. accessed 5 September 2015.

McQuail, D. (1994) Mass Communication Theory. Sage Publications: London. Pp.127-128.

Magen, A. (2012) 'On Political Order and the 'Arab Spring', (in) Israel Journal of Foreign Affairs, Vol. I:1:, P. 10. Israel Council on Foreign Affairs: Tel Aviv. Pp. 9-21. http://www.israelcfr.com/ documents/6-1/6-1-2-Magen.pdf. accessed 5 September 2015.

Owais, R. (2011) 'Arab Media during the Arab Spring in Egypt and Tunisia: Time for Change', (in) Middle East Media Educator, 1, Issue 1. University of Wollongong: Australia Vol.1, Issue 1. Pp.913. Available at: http://ro.uow.edu.au/meme. accessed 5 September 2015.

Peterson, J. E. (2012) The GCC states:

Participation, opposition, and the fraying of the social contract. LSE Department of Government, Kuwait Programme on Development, Governance 
and Globalisation in the Gulf States: London. http://eprints.Ise.ac.uk/.pdf. accessed 5 September 2015.

Peterson, M. (2011) 'Egypt's Media Ecology in a Time of Revolution', (in) Arab Media and Society. Issue no. 13, Spring 2011. Kamal Adham Center for Television and Digital Journalism, the American University in Cairo: Cairo. Pp. 1-16. Available at: http://www.arabmediasociety.com/. accessed 5 September 2015.

Rugh, W. (1989) The Arab Press, New Media and the Political Process in the Arab World. Syracuse University Press: New York.

Samin, N. (2012) 'Saudi Arabia, Egypt, and the Social Media Moment', (in) Arab Media\& Society, issue 15, Spring 2012. http://www. arabmediasociety.com/?article. accessed 20 August 2015.

Schmidt, A. and Vannahme, J. (2012) The Arab Spring: One Year After. Europe in Dialogue. Bertelsmann Stiftung: Gütersloh. https://www. bertelsmann-stiftung.de/fileadmin/files/.pdf. accessed 20 August 2015.

Storck, M. (2011) The Role of Social Media in Political Mobilisation: a Case Study of the January 2011 Egyptian Uprising. M.A. dissertation. University of St Andrews, Scotland. http://www. culturaldiplomacy.org/academy/content/pdf/ participant-papers/.pdf. accessed 20 August 2015.

The Public Authority for Radio and Television website: www.http://part.gov.om/part/. accessed 20 August 2015.

United Nations Development Programme (UNDP) Regional Bureau for Arab States (2009) Arab Human Development Report "Challenges to Human Security in the Arab Countries". New York: USA. P.131. Available also on: Web: www.undp.org/rbas and www.arab-hdr.org. accessed 22 July 2015.
USAID United States Agency for International Development (2011) The 2011 Civil Society Organization Sustainability Report for the Middle East and North Africa. Bureau for Democracy, Conflict, and Humanitarian Assistance Center of Excellence on Democracy, Human Rights, and Governance Bureau for the Middle East Office of Middle East Program. https://www.usaid.gov/ sites/default/files/documents/.pdf. accessed 5 September 2015.

Valeri, M. (2015) Simmering Unrest and Succession Challenges in Oman. http:// carnegieendowment.org/2015/01/28/simmeringunrest-and-succession-challenges-in-oman/. accessed 5 September 2015.

Watanserb (2015) 'Controlling the Tale: Press Flourished for Short Time and then Dulled'. http://www.watansearb.com/archive1/reports/ July 28, 2015). accessed 20 August 2015. 